\title{
Attitudes and Practices of Indians during the Covid-19 Pandemic
}

\author{
Aniruddh Agrawal ${ }^{1, *}$, Anisha Agrawal' ${ }^{1}$ Tanisha Baid ${ }^{2}$
}

\begin{abstract}
Background: The SARS-CoV-2 led to a nationwide lockdown in India from $24^{\text {th }}$ March, 2020. It became important to identify people's attitudes and practices to allow rapid change in health policies to alleviate stress factors. Objectives: To evaluate the attitudes, practices and sources of information and their perceived reliability from people residing in India. Methods: An online-based survey which asked respondents about the change in their practices due to the pandemic and their opinions on the measures taken to prevent spread of the virus. was conducted on 29 $9^{\text {th }}$ March, 2020. 995 individuals (Average age - 42.8 years) responded from 24 states of India. Participants were invited to respond through the survey through dissemination of a link through online social media platforms. Only people who were residing in India were included in the study. Results: $58.6 \%$ were highly concerned about contracting the virus. $51.9 \%$ had stepped out during the lockdown period, most commonly to buy groceries (37.2\%). $45 \%$ respondents faced mask shortages leading to prolonged use of the same mask (average 6.74 hours). $29.3 \%$ paid above the maximum retail price for their masks. Although people favored laws making self-isolation (95.2\%) and mask wearing in public (81.5\%) compulsory, support fell on introduction of a jail term for violating the law. Health care professionals were considered the most reliable source of information (4.42/5) followed by public health officials (4.03/5). However, $60.4 \%$ of the population used newspapers, magazines, etcetera for their information. Conclusion: People seem to rely on information sources that they themselves claim to be of inferior reliability. People generally support laws with fines to ensure prevention of virus transmission but do not support jail terms to these laws.
\end{abstract}

Key words: Coronavirus, India, Quarantine, Attitudes (Source: MeSH:NLM).

\section{Aniruddh Agrawal ${ }^{1, *}$, Anisha Agrawal ${ }^{1}$, Tanisha Baid $^{2}$ \\ 'Topiwala National Medical College, Mumbai Central, Mumbai 400008, Maharashtra, INDIA. \\ ${ }^{2}$ Chauhan Institute of Science, Andheri West, Mumbai, Maharashtra, INDIA.}

\section{Correspondence}

Dr. Aniruddh Agrawal,

401 Sony House, CD Barfiwala Road,

Andheri West, Mumbai-400056,

Maharashtra, INDIA.

Mobile no: +919619004904

Email: ani@pubgeek.co

History

- Submission Date: 29-06-2020

- Revised Date: 17-07-2020

- Accepted Date: 24-09-2020

DOI : 10.5530/ijmedph.2020.4.38

Article Available online

http://www.ijmedph.org/v10/i4

\section{Copyright}

(C) 2020 Phcog.Net. This is an openaccess article distributed under the terms of the Creative Commons Attribution 4.0 International license.

\section{INTRODUCTION}

SARS-CoV-2 was declared a global pandemic by the World Health Organisation (WHO) on $11^{\text {th }}$ March, 2020, ${ }^{1}$ following which many governments established lockdown of entire countries which prevented all people from stepping out of their homes, other than for delivering or receivoing essential services. ${ }^{2,3}$ The Environmental spread of this virus was determined to be the primary method of transmission of this disease. In the month of March, the Government of India, issued a number of advisories to the general public which shaped their perception towards the disease. $^{4-6}$

Similar studies on practices and attitudes of populations to a similar virus outbreak had been conducted in Taiwan, Singapore, Hong Kong, the United States ${ }^{7}$ and Australia ${ }^{8}$ during the previous SARS-CoV-1 pandemic and the H1N1 virus. Although at the time conducting the study, no literature evidence was available of a similar study being conducted in India, since then a few studies highlighting information on attitudes of people towards SARS-CoV-2 have been published. However, a majority of the studies that have been conducted in

Cite this article : Agrawal A, Agrawal A, Baid T. Attitudes and Practices of Indians during the Covid-19 Pandemic. Int J Med Public Health. 2020;10(4):174-9. 
knowledge that individuals rely upon during a pandemic. This would not only help in rapidly evolving public health policies for the SARS-CoV-2 pandemic but can be applied to future lockdown procedures.

\section{MATERIALS AND METHODS}

\section{Study environment}

India's first SARS-CoV-2 case was detected on January $30^{\text {th }}, 2020$ in the state of Kerala. ${ }^{15} 7$ weeks later, a 14 hour, civil, self-imposed curfew was recommended by the Prime Minister of India on $22^{\text {nd }}$ March, 2020. ${ }^{16}$ Following this, the government of India recommended complete lockdown of the nation for 21 days starting from $24^{\text {th }}$ March, 2020 which meant that a total ban was being imposed on people from stepping out of their homes, except for those who wanted to retrieve essential services or were part of the essential services. ${ }^{17}$ This survey was electronically distributed on $29^{\text {th }}$ March, 2020, five days into the nationwide lockdown.

\section{Survey Questionnaire}

Through the help of literature analysis and expert opinion, we were able to formulate a questionnaire with 59 questions, 54 of which were multiple choice questions. Information elicited by the questions included respondents' demographic details, their socioeconomic class using the Kuppuswamy Socioeconomic Scale updated for the year 2019, ${ }^{18}$ their obedience with the lock-down norms, their opinion of the lockdown norms, their concern about becoming ill with the SARS-CoV-2, their opinion on measures to protect the public, preferences for where they would be quarantined, opinion on measures to monitor compliance with quarantine, worries about quarantine, and preferred sources of information and their perceived efficacy during the pandemic. This survey was designed and elicited using a web-based survey portal at https://www.surveysparrow.com/ and was available only in the English language.

\section{Survey Respondents}

The survey was disseminated with the help of social networking websites and applications (Twitter, Facebook and Whatsapp) to large groups of audiences. No paid promotion was done for people to answer this survey. The link to the survey was shared through the authors' social medial handles on various platforms. Due to this, the total response rates are not available for the survey. All people who completed the survey were included in the study, any person who was not a resident of India was excluded from the study. A total of 999 people completed the survey, out of which 4 resided outside India and were excluded. Therefore, data was collected from the 995 respondents (Average age -42.8 years) that met all inclusion and exclusion criteria. No respondent was provided with any remuneration for answering the survey, financial or otherwise.

\section{Statistical Analyses}

All analyses were conducted using the SPSS v24 software. ${ }^{19}$ We presented continuous variables as means with $95 \%$ class interval and/or range of responses. For categorical variables, descriptive statistics were calculated as percentages. Correlation analysis was performed with the help of Pearson Correlation for continuous variables and Mann-Whitney-U test for correlation between ordinal and nominal variables.

\section{Ethics Statement}

This study was approved by an Institutional Review Board. At the start of the questionnaire, all participants read and accepted an informed consent statement. All responses to the questionnaire were anonymized and entered into an online questionnaire database.

\section{Limitations}

Although this study tries to report about attitudes of Indians towards the SARS-CoV-2 pandemic, it has limitations in that the respondents of this study do not proportionally represent the population of India. The socio-economic status of the respondents was different than that reported by the Indian census in $2011,{ }^{20}$ however, there may have been changes in the socio-economic strata in the last 9 years which may help in the extrapolation of our findings to the broader population. Another limitation was that most of the respondent population was from one state, however, there were participants from 24 different states which gave a broader general view of the Indian population. Although a population representative household survey would have been ideal, it would have taken months of preparation and data collection which would have made the findings obsolete due to the rapidly emerging changes in the pandemic. ${ }^{13}$

\section{RESULTS}

\section{i) Demographic and Socioeconomic Information}

Out of 995 respondents, 490 (49.2\%) were male and 504 (51.8\%) were females. One respondent identified themselves as 'other'. The average age of respondents was 34.15 years (SD: 15.02 years). Although the respondents resided in 24 different states and/or union territories, a majority of the responses were from the state of Maharashtra (76.1\%). The number of respondents from each state has been illustrated in Table 1. Table 2 gives information about the socio-economic and household status of the respondents. As reported by the Kuppuswamy Socioeconomic Status Scale, most respondents were from the upper class $(64.8 \%)$ and the upper middle class $(28.9 \%)$.

\section{ii) Household Information}

The average number of people in each of the respondents' household were 4.41 (SD: 2.77 ) and 53.8\% of respondents had at least one senior citizen (defined as adult above 65 years of age) living in their household. On the scale of $0-5$ of how concerned the respondents were of themselves or someone in their household contracting SARS-CoV-2 virus, $13.1 \%$ chose 0 indicating that they were not at all concerned, $28.3 \%$ chose between 1-3 indicating slight to moderate concern and $58.6 \%$ chose $4-5$ indicating high concern. (Figure 1)

The concern for contracting SARS-COV-2 themselves or family members was neither statistically correlated to the number of people in their household $(\mathrm{r}=0.016, \mathrm{p}=0.60)$ nor the number of senior citizens in their household $(r=-0.22, p=0.53)$.

\section{iii) Acquaintance with a person suffering from SARS-}

\section{CoV-2}

$3 \%(n=30)$ respondents said that they personally knew someone who had contracted the SARS-CoV-2 disease. However, the respondents' concern for contracting SARS-CoV-2 themselves or family members was not statistically correlated to them knowing a person suffering from SARS-CoV-2. (Mann Whitney U test, $\mathrm{p}=0.19$ ).

\section{iv) Activity during and before lockdown}

904 (90.9\%) respondents reported that they had put themselves in voluntary self-isolation even before lockdown measures were implemented by the government. On average, respondents had isolated themselves for 10.55 days (SD - 3.98), preceding them answering the questionnaire. Only 51.9\% $(\mathrm{n}=516)$ of respondents had stepped out of their apartments for an average of 3.18 times (SD - 3.94) in the preceding 7 days. Only $14.7 \%(n=146)$ had gone to their office/school in the preceding 7 days. The most common reason for stepping out was 
shopping for groceries $37.2 \%(n=370)$ followed by visit to pharmacy $16.6 \%(n=165)$. Table 3 highlights the respondents' different reasons for stepping out in the 7 days preceding them answering the questionnaire. An additional 27.2\% $(n=271)$ had stepped out of their homes in the preceding 15 days for an average of 10.65 (SD-12.5) times.

\section{v) Information on mask wearing compliance and availability}

$84.92 \%(n=845)$ of respondents purchased a mask during the pandemic. Most common mask bought by the respondents was a surgical mask (42.1\%). $11.38 \%(n=92)$ of the respondents who had bought masks also reportedly wore it inside their homes to avoid contracting the coronavirus, although none of these respondents had any SARS-CoV-2 positive patients in their households. On average the respondents wore the same mask for 6.74 hours (SD- 9.64 hours). $45 \%(n=448)$ people said that they faced shortage of masks and $29.3 \%(n=292)$ said that they paid above the maximum retail price (MRP) for their masks.

\section{vi) Hand Hygiene Knowledge and Compliance}

$86.83 \%$ ( $n=864$ ) of respondents thought that hand washing with nonmedicated soap was equal to or even better than using an alcohol-based sanitizer. 55.9\% $(\mathrm{n}=556)$ respondents faced shortage of hand sanitizers. However, 19.6\% $(n=195)$ respondents did not check whether their sanitizer was alcohol based or not before purchasing it.

\section{Table 1: Opinions about Laws that could be implemented during the} pandemic.

\begin{tabular}{|c|c|c|c|}
\hline \multicolumn{2}{|c|}{ A law with respect to Self-Isolation } & Favor & Oppose \\
\hline \multicolumn{2}{|c|}{$\begin{array}{l}\text { Having a law making self-isolation } \\
\text { compulsory }\end{array}$} & $95.2 \%(n=947)$ & $4.8 \%(n=48)$ \\
\hline \multicolumn{2}{|c|}{$\begin{array}{l}\text { Having a monetary fine if caught } \\
\text { breaking the law }\end{array}$} & $\begin{array}{l}89.12 \%(n=844 \\
\text { out of } 947)\end{array}$ & $\begin{array}{c}10.87 \%(n=103 \\
\text { out of } 947)\end{array}$ \\
\hline \multicolumn{4}{|c|}{ How much should the fine be? (in INR) } \\
\hline Amount & $\begin{array}{l}\text { Support by } \% \text { of } \\
\text { respondents (out of } \\
\text { 844) }\end{array}$ & & \\
\hline 200 & $13.99 \%$ & & \\
\hline 500 & $25.57 \%$ & & \\
\hline 1,000 & $28.79 \%$ & & \\
\hline 5,000 & $20.74 \%$ & & \\
\hline 10,000 & $10.91 \%$ & & \\
\hline \multicolumn{2}{|c|}{$\begin{array}{l}\text { Having a jail term if caught breaking the } \\
\text { law }\end{array}$} & $\begin{array}{c}48.78 \%(n=462 \\
\text { out of } 947)\end{array}$ & $\begin{array}{c}51.21 \%(n=485 \\
\text { out of } 947)\end{array}$ \\
\hline \multicolumn{4}{|c|}{ How much should the jail term be? } \\
\hline $\begin{array}{l}\text { Length of } \\
\text { term }\end{array}$ & $\begin{array}{l}\text { Support by \% of } \\
\text { respondents (out of } 462 \text { ) }\end{array}$ & & \\
\hline 1 day & $20.57 \%$ & & \\
\hline 4 days & $12.99 \%$ & & \\
\hline 7 days & $25.54 \%$ & & \\
\hline 2 weeks & $16.23 \%$ & & \\
\hline 1 month & $13.85 \%$ & & \\
\hline$\geq 2$ months & $10.82 \%$ & & \\
\hline
\end{tabular}

This table highlights the opinion of the individuals on a potential law of selfisolation and whether they still supported it if a fine was introduced for violating the law and if a jail term was introduced for violating the law.

\section{vii) Attitude towards laws and practices during the isolation period}

\section{a) Laws related to isolation (Table 1)}

95.2\% $(\mathrm{n}=947)$ of the respondents said that they would support a law that made self-isolation compulsory other than for retrieving and delivering essential services. $89.12 \%,(n=844$ out of 947$)$ respondents showed support for introducing a fine for violating this isolation law. However, support fell to $48.78 \%$ ( $n=462$ out of 947) for introducing a jail term for violating the law. Most respondents $(54.38 \%, n=459$ out of 844 that supported a fine) recommended a fine between INR 5001000. Most respondents $(59.52 \%, n=275$ out of 462 that supported a jail term) recommended a term between 1-7 days. There was no statistically significant correlation between support for having a fine for violating the law or the amount of fine for violating the law and the socio-economic status of the respondent. ( $\mathrm{p}=0.17$, between upper class and lower middle class).

\section{b) Laws related to mask compliance (Table 2)}

$81.5 \%$ ( $\mathrm{n}=811$ ) of the respondents said that they would support a law that made mask wearing compulsory for up to 4 months after the end of the lockdown period. $83.97 \%$ ( $n=674$ out of 811 ) of the respondents showed support for introducing a fine for breaking the law. However, support fell to $31.44 \%$ ( $n=255$ out of 811 ) for introducing a jail term for violating

Table 2: Opinion about Mask compliance and laws.

A law with respect to Mask compliance
Having a law making wearing of masks
in public places compulsory for 4 months
after the end of the lockdown
Having a monetary fine if caught breaking
the law
How much should the fine be? (in INR)
Amount $\quad$ Support by \% of
$\begin{array}{cc}200 & 27.78 \% \\ 500 & 31.89 \% \\ 1,000 & 24.11 \% \\ 5,000 & 10.46 \% \\ 10,000 & 5.76 \%\end{array}$

Having a jail term if caught breaking the law

$31.44 \%(n=255 \quad 68.56 \%(n=556$

$83.97 \%(n=681 \quad 16.07 \%(n=130$ out of 811$) \quad$ out of 811$)$

\begin{tabular}{lc}
\multicolumn{1}{c}{ Favor } & \multicolumn{1}{c}{ Oppose } \\
\hline $81.5 \%(n=811)$ & $18.5 \%(n=184)$ \\
& \\
$\begin{array}{l}83.97 \%(n=681 \\
\text { out of } 811)\end{array}$ & $\begin{array}{l}16.07 \%(n=130 \\
\text { out of } 811)\end{array}$
\end{tabular}
out of 811$)$ out of 811 )

How much should the jail term be?

$\begin{array}{cc}\begin{array}{c}\text { Length of } \\ \text { term }\end{array} & \begin{array}{c}\text { Support by } \% \text { of } \\ \text { respondents (out of } \\ 255)\end{array} \\ 1 \text { day } & 30.20 \% \\ 4 \text { days } & 14.90 \% \\ 7 \text { days } & 25.49 \% \\ 2 \text { weeks } & 9.80 \% \\ 1 \text { month } & 10.20 \% \\ \geq 2 \text { months } & 9.41 \%\end{array}$

This table highlights the opinion of the individuals on a potential law of making masks compulsory in public spaces and whether they still supported it if a fine was introduced for violating the law and if a jail term was introduced for violating the law. 
the law. Most respondents $(84.57 \%, \mathrm{n}=570$ out of 674 that supported a fine) recommended a fine between INR 200-1000. Most respondents (74.50\%, n=190 out of 255 that supported a jail term) recommended a term between 1-7 days. There was no statistically significant correlation between support for having a fine for violating the law or the amount of fine for violating the law and the socio-economic status of the respondent. ( $p=0.46$, between upper class and lower middle class)

\section{c) Concerns during the self-isolation period}

The most common cause for concern was getting medical care from doctors ( $49.9 \%, \mathrm{n}=497)$, followed by getting groceries $(32 \%, n=318)$.

d) Monitoring of self-isolation or home quarantine by public health officials (Table 3)

When given the options of which method they would approve of public health officials using to make sure people abided by home-quarantine or self-isolation, the most respondents supported periodic telephone calls (89\%) and least support was received by an electronic tracking bracelet (71.8\%).

\section{Table 3: Monitoring of self-isolation or home quarantine by public} health officials.

\begin{tabular}{|cc|}
$\begin{array}{c}\text { Method used by public health } \\
\text { officials for monitoring self- } \\
\text { isolation or home quarantine }\end{array}$ & $\begin{array}{c}\text { Percentage of Respondents that } \\
\text { approve }\end{array}$ \\
\hline Periodic Telephone Calls & $89 \%(n=886)$ \\
Guards Stationed on Every Street & $82.5 \%(n=821)$ \\
Periodic Video Screening & $78.4 \%(n=780)$ \\
Daily Visit by Public Health Officials & $75.3 \%(n=749)$ \\
Electronic Location Tracking Bracelet & $71.8 \%(n=714)$ \\
\hline
\end{tabular}

This table shows the approval rate for different methods that the government could use for monitoring compliance with stay-at-home orders.

Table 4: Attitudes of people about quarantine measures.

\begin{tabular}{|c|c|c|}
\hline Attitude about & Options & $\begin{array}{l}\text { Percentage of } \\
\text { respondents }\end{array}$ \\
\hline $\begin{array}{l}\text { Location of quarantine } \\
\text { for or immediate family } \\
\text { members who are } \\
\text { infected }\end{array}$ & Separate medical facility & $\begin{array}{l}28.7 \%(n=286) \\
71.3 \%(n=709)\end{array}$ \\
\hline $\begin{array}{l}\text { Location of quarantine } \\
\text { for themselves, if } \\
\text { infected }\end{array}$ & Separate medical facility & $\begin{array}{l}24.5 \%(n=244) \\
75.5 \%(n=751)\end{array}$ \\
\hline \multirow{5}{*}{$\begin{array}{l}\text { Concerns if respondents } \\
\text { were taken to a } \\
\text { government medical } \\
\text { facility for quarantine if } \\
\text { they were suspected of } \\
\text { contracting the virus }\end{array}$} & $\begin{array}{l}\text { Being exposed to someone } \\
\text { who actually is infected with } \\
\text { SARS-CoV-2 }\end{array}$ & $76.5 \%(n=761)$ \\
\hline & $\begin{array}{l}\text { Inadequate hygiene at place } \\
\text { of quarantine }\end{array}$ & $58.7 \%(n=584)$ \\
\hline & $\begin{array}{c}\text { Overcrowding at place of } \\
\text { quarantine }\end{array}$ & $56.8 \%(n=565)$ \\
\hline & $\begin{array}{l}\text { Inadequate medical care at } \\
\text { facility }\end{array}$ & $46.6 \%(n=464)$ \\
\hline & $\begin{array}{l}\text { Being unable to } \\
\text { communicate with family } \\
\text { members }\end{array}$ & $39.2 \%(n=390)$ \\
\hline
\end{tabular}

This table highlights what location individuals would want their loved ones/ themselves to be quarantined in if infected and also the different concerns that they had, if they were forced to be quarantined at a government medical facility.
When respondents were asked if they would voluntarily report to authorities if they observe someone breaking self-isolation norms, 87.8\% said that they would but out of these, only $40.3 \%$ knew where they would report such a person.

\section{viii) Attitude towards quarantine (Table 4)}

$76 \%(n=756)$ of respondents said that they would support passing a law that would force persons who is suspected to be exposed to the virus to be quarantined in a facility that is decided by the government and not the exposed persons themselves. However, on enquiring where they would rather have a family member quarantined if he/she contracted the virus, $71.3 \% \quad(n=709)$ respondents said they would prefer to have them quarantined at a separate medical facility rather than home. A higher percentage of people, $75.5 \%(n=751)$, said that if they themselves contracted the virus, they would prefer to be taken to a medical facility for quarantine. Some of the most important concerns that people had, should they be taken to a government facility for quarantine if they were suspected to be infected by SARS-CoV-2, were, being exposed to someone who actually is infected by the virus $(76.5 \%)$ and inadequate hygiene at the place of quarantine (58.7\%).

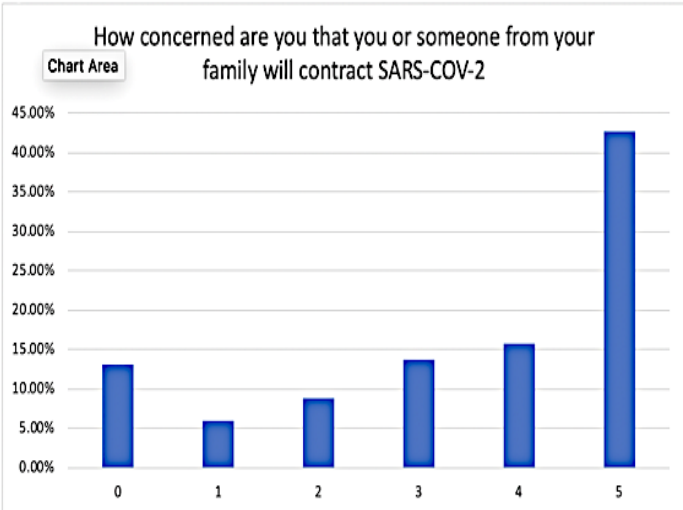

Figure 1: This is Figure Number 1 which represents the likert scale (1-5) for which people graded how scared they were that someone from their family or they themselves would contract the coronavirus.

Table 5: The source of information that people relied on and that they found to be tthe mostt reliable.

\begin{tabular}{ccc}
\hline Source of Information & $\begin{array}{c}\text { Percentage of } \\
\text { respondents that } \\
\text { use it }\end{array}$ & $\begin{array}{c}\text { Reliability score (Mean } \\
\text { score out of 5) }\end{array}$ \\
$\begin{array}{c}\text { Magazine/ TV/ Radio/ } \\
\text { Newspapers } \\
\text { Government / Public } \\
\text { Health Authorities }\end{array}$ & $30.4 \%(n=601)$ & $3.13(\mathrm{SD}-1.090)$ \\
$\begin{array}{c}\text { Messages / Documents / } \\
\text { Videos on WhatsApp }\end{array}$ & $35.6 \%(n=354)$ & $1.03(\mathrm{SD}-0.98)$ \\
$\begin{array}{c}\text { Doctor / other health } \\
\text { care professional }\end{array}$ & $31.9 \%(n=317)$ & $4.42(\mathrm{SD}-0.79)$ \\
$\begin{array}{c}\text { Family and Friends } \\
\text { Official WHO channel } \\
\text { on website or WhatsApp }\end{array}$ & $23.7 \%(n=236)$ & $2.18(\mathrm{SD}-1.03)$ \\
\hline
\end{tabular}

This table highlights the sources of information that people used as well as how reliable they thought that a particular source of information was. 


\section{ix) Sources of information and perceived reliability} (Table 5)

The most common sources of information used by respondents were Newspapers, magazines, radio and TV $(60.4 \%)$ followed by Government and Public Health Authorities (38.3\%). Respondents perceived doctors and other healthcare professionals to be the most reliable source of information (mean reliability score of 4.42 out of 5) followed by Government and public health authorities (mean reliability score 4.03 out of 5). Information distributed on the instant messaging platform WhatsApp was perceived to be least reliable. (Mean reliability score 1.52 out of 5).

\section{DISCUSSION}

The SARS-CoV-2 pandemic has led to a complete lockdown of 1.2 billion people in India for a period of 21 days, with possible extensions in sight. ${ }^{17}$ This presents researchers with a unique opportunity to understand the attitudes and practices of people towards a pandemic. It is also important to understand and account for the international variability in attitudes, beliefs and practices. ${ }^{21}$

4.4 people resided per household in our study population, which is almost twice that of the United States, ${ }^{22}$ which could explain the high level of concern that they had for their family members contracting the virus. (Figure 1) Although the elderly are more susceptible to the disease $^{23}$ there was, however, no correlation between having a senior citizen in the household and concern for a family member contracting the virus.

Not unlike the people in the United States and the United Kingdom which supported the lockdown measures, as reported by Geldsetzer ${ }^{24}$ most of the respondents had decided to pre-emptively self-isolate to prevent contracting and/or spreading the infection.

The goal of the lockdown procedure taken by the government was to ensure that people would not step outside their homes, however, 51.9\% of people had left their homes during the quarantine period. Therefore, in order to limit the movement of people, the most common reasons for them to step out need to be identified and then dealt with in accordance with local guidelines. The most common factors that would greatly reduce such movement include supply of groceries direct-to-doorstep and supply of necessary medication. As almost $50 \%$ of people showed concerns about getting their groceries during this self-isolation period, this assurance of door-step-delivery would help reduce tensions.

Although masks were purchased by about $80 \%$ of the respondents, around $22 \%$ were wearing masks made from cloth, which have shown to be ineffective in preventing viral illnesses in the wearer. ${ }^{25}$ This therefore can cause a false sense of security and increase infection rates among wearers. ${ }^{26}$ On the other hand, shortages of masks and hand sanitizers affected almost $50 \%$ of the people leading to them using masks for almost 7 hours, whereas Barbosa et al. have reported that the bacterial filtration efficacy of most masks decreases after 4 hours of continuous wear. ${ }^{27}$ A possible method to promote rational use of masks would be to ask people to avoid wearing masks at home if there is no threat from a SARS-COV-2 positive patient at home, something that almost $12 \%$ of the respondents had done. Another worrisome aspect was the pricing above that of the maximum retail price, although the government had, on $21^{\text {st }}$ March capped the prices of double and triple ply masks. ${ }^{28}$ However, because $26.5 \%$ of the respondents didn't know the MRP of the masks, it becomes important to spread this public awareness. Another aspect needing public awareness is the fact that only alcohol based sanitizers are effective against coronaviruses and not chlorhexidine ${ }^{29}$ as almost $20 \%$ of the respondents hadn't checked whether their hand sanitizer contained alcohol or not before purchasing it.
A whopping $86.83 \%$ of individuals thought that hand washing with medicated soap was equal to or better than using an alcohol-based sanitizer, while in reality usage of soap has no microbicidal effect on enveloped viruses. ${ }^{30}$

When asked to give opinions on different laws and practices that could be instituted, respondents were generally in favor of laws forcing people to isolate and wear masks in public and were even tolerant to fines on violations. However, like the regions of Taiwan, Singapore, United States and Hong Kong ${ }^{7}$ support fell for these laws if jail terms were introduced for violations. Although one would expect that people of a higher socio-economic class would be more tolerant to having higher fines for law violations, it was interesting to see that there was no statistically significant change between the socio-economic classes.

The Indian respondents were more supportive of electronic location tracking bracelets and guards stationed on every street than the US, Hong Kong, Taiwan or Singapore, ${ }^{7}$ however, support for daily visit by a public health professional was lowest in Indians among the five countries. This could possibly stem from some sort of distrust with public health authorities in India as if it was a matter of obtrusion of privacy, a much lesser percentage of people would have supported an electronic location tracking bracelet.

Although people in the United States, Singapore and Taiwan, preferred home quarantine, ${ }^{7}$ there was strong support in India towards quarantine at a separate medical facility, for both relatives as well as the respondents themselves. This result closely resonates with the opinion of people from Hong Kong.

Concerns about improper infection control, inadequate hygiene and overcrowding at government medical facilities were commonplace and should be addressed to allay people's fears which would prevent them from hiding potential diagnoses and symptoms and decrease community spread of the virus.

Not unlike the United States, Taiwan, Singapore, Hong Kong, ${ }^{7}$ doctors were considered the most reliable source of information in India. Although there was a genuine sense of mistrust amongst public health departments in the United States and Taiwan, ${ }^{7}$ however, not unlike Australia ${ }^{8}$ the public health authorities in India drew high reliability scores from the respondents. A concerning statistic was that, although considered to be the most reliable, these sources were being used by a smaller fraction of the population than those that were relying on magazines, TV, radio, newspapers and instant messaging services like WhatsApp for their information.

A study conducted by Dkhar et al. ${ }^{31}$ limited to the state of Jammu and Kashmir in India also reported that $36 \%$ people faced issues with obtaining essential commodities and services in that state, compared to almost $50 \%$ in our studies that faced a problem with getting medical attention from doctors. Around $85 \%$ people agreed with practice of selfisolation or home quarantine in this study, similar to the $95 \%$ agreement in our study. However, a large deviation from this study by Dkhar et al. ${ }^{31}$ which said that only $35 \%$ of respondents supported wearing masks in public, our study reported support for this measure at $85 \%$. Most other surveys conducted in India were related to opinions and perceptions of healthcare works and therefore a direct comparison between these studies and our reports would be an unfair assessment. ${ }^{9-11,32}$

\section{CONCLUSION}

People are taking an active response to the lockdown measures imposed by the government, however, certain pain-points like getting groceries and medications are preventing efficient implementation of these procedures. People's use of unreliable sources of information may lead to spread of misinformation and panic. To evaluate misinformation, future 
studies should focus on knowledge of people towards the pandemic and correlate it with sources of information that they use. Further studies should be performed using representative population data to get a complete picture of the attitudes and practices of the Indian citizenry.

\section{ACKNOWLEDGEMENT}

We would like to thank PubGeek.Co for the opportunity to complete this study.

\section{CONFLICT OF INTEREST}

The authors declare no Conflict of interest.

\section{REFERENCES}

1. World Health Organisation. WHO Director-General's opening remarks at the media briefing on COVID-19 - 11 March 2020. Accessed 13 ${ }^{\text {th }}$ April, 2020. https:// www.who.int/dg/speeches/detail/who-director-general-s-opening-remarks-atthe-media-briefing-on-covid-19--11-march-2020

2. Ministry of Housing CLG, United Kingdom. Government announces further measures on social distancing. Accessed $13^{\text {th }}$ April, 2020. https://www.gov.uk/ government/news/government-announces-further-measures-on-social-distancing

3. Government of India. PM calls for complete lockdown of entire nation for 21 days Accessed $7^{\text {th }}$ April, 2020. https://pib.gov.in/newsite/PrintRelease. aspx? relid $=200658$

4. Government Of India. Posters for Safety measures against COVID-19 - English. https://www.mohfw.gov.in/pdf/ProtectivemeasuresEng.pdf

5. Government of India. When to get tested for COVID-19 English. Accessed 14 September, 2020. https://www.mohfw.gov.in/pdf/FINAL_14_03_2020_ENg.pdf

6. Government of India. What is the Novel Coronavirus? Accessed 14 September, 2020. https://www.mohfw.gov.in/pdf/Poster1GHFandDH.pdf

7. Blendon RJ, DesRoches CM, Cetron MS, Benson JM, Meinhardt T, Pollard W. Attitudes toward the use of quarantine in a public health emergency in four countries. Health Aff (Millwood). Mar-Apr 2006;25(2):w15-25. doi:10.1377/ hlthaff.25.w15

8. Kavanagh AM, Bentley RJ, Mason KE, et al. Sources, perceived usefulness and understanding of information disseminated to families who entered home quarantine during the H1N1 pandemic in Victoria, Australia: a cross-sectional study. BMC Infect Dis. 2011:2.

9. Bhagavathula AS, Aldhaleei WA, Rahmani J, Mahabadi MA, Bandari DK. Knowledge and Perceptions of COVID-19 Among Health Care Workers: Cross-Sectional Study. JMIR Public Health Surveill. Apr 30 2020:6(2):e19160. doi:10.2196/19160

10. Kamate SK, Sharma S, Thakar S, et al. Assessing Knowledge, Attitudes and Practices of dental practitioners regarding the COVID-19 pandemic: A multinational study. Dent Med Probl. Jan-Mar 2020;57(1):11-17. doi:10.17219/dmp/119743

11. Parikh PA, Shah BV, Phatak AG, et al. COVID-19 Pandemic: Knowledge and Perceptions of the Public and Healthcare Professionals. Cureus. May 15 2020;12(5):e8144. doi:10.7759/cureus.8144

12. Pal R, Yadav U, Grover S, Saboo B, Verma A, Bhadada SK. Knowledge, attitudes and practices towards COVID-19 among young adults with Type 1 Diabetes Mellitus amid the nationwide lockdown in India: A cross-sectional survey. Diabetes Research and Clinical Practice. 2020;166:2020. doi: https://doi.org/10.1016/j. diabres.2020.108344

13. Gong W, Taighoon Shah M, Firdous S, et al. Comparison of three rapid house- hold survey sampling methods for vaccination coverage assessment in a periurban setting in Pakistan. Int J Epidemiol. 2019;48(2):583-95. doi:10.1093/ije/ dyy263

14. Abraham KG, Presser S, Helms S. How social processes distort measurement: the impact of survey nonresponse on estimates of volunteer work in the United States. Ajs. Jan 2009;114(4):1129-65. doi:10.1086/595945

15. India Go. Update on Novel Coronavirus: one positive case reported in Kerala. https://pib.gov.in/PressReleaselframePage.aspx?PRID=1601095

16. India Go. Appeal to observe Janta curfew tomorrow from 7 AM to 9 PM https:// pib.gov.in/newsite/PrintRelease.aspx?relid=200578

17. India Go. PM calls for complete lockdown of entire nation for 21 days Accessed $7^{\text {th }}$ April, 2020. https://pib.gov.in/newsite/PrintRelease.aspx? relid=200658

18. Wani R. Socioeconomic status scales-modified Kuppuswamy and Udai Pareekh's scale updated for 2019. Review Article. Journal of Family Medicine and Primary Care. June 1, 2019 2019;8(6):1846-1849. doi:10.4103/jfmpc. jfmpc_288_19

19. IBM SPSS Statistics. Version 22. 2013

20. Government of India - Census Bureau. Census Info India 2011. Accessed April 13, 2020. http://www.dataforall.org/dashboard/censusinfo/

21. Bekker FJ, Hentschel U, Fujita M. Basic cultural values and differences in attitudes towards health, illness and treatment preferences within a psychosomatic frame of reference. Psychother Psychosom. 1996;65(4):191-8. doi:10.1159/000289074

22. United States Census Bureau. Table HH-4. Households by Size: 1960 to Present\&\#x9;. Accessed 12 April, 2020. https://www.census.gov/data/tables/ time-series/demo/families/households.html

23. Wang $X$, Fang J, Zhu $Y$, et al. Clinical characteristics of non-critically ill patients with novel coronavirus infection (COVID-19) in a Fangcang Hospital. Clin Microbiol Infect. Apr 3 2020;doi:10.1016/j.cmi.2020.03.032

24. Geldsetzer P. Use of Rapid Online Surveys to Assess People's Perceptions During Infectious Disease Outbreaks: A Cross-sectional Survey on COVID-19. J Med Internet Res. Apr 2 2020;22(4):e18790. doi:10.2196/18790

25. Maclntyre CR, Seale H, Dung TC, et al. A cluster randomised trial of cloth masks compared with medical masks in healthcare workers. BMJ Open. Apr 22 2015;5(4):e006577. doi:10.1136/bmjopen-2014-006577

26. World Health Organisation. Advice on the use of masks the community, during home care and in health care settings in the context of the novel coronavirus (2019-nCoV) outbreak. Accessed 12th April, 2020. https://www.who.int/docs/ default-source/documents/advice-on-the-use-of-masks-2019-ncov.pdf

27. Barbosa MH, Graziano KU. Influence of wearing time on efficacy of disposable surgical masks as microbial barrier. Brazilian Journal of Microbiology. 2006;37:216-217.

28. Government of India. Govt caps prices of hand sanitizers, masks; States/UTs asked to maintain essential supplies. Accessed $12^{\text {th }}$ April, 2020. https://pib.gov. in/PressReleseDetailm.aspx?PRID $=1607528$

29. Kampf G, Todt D, Pfaender S, Steinmann E. Persistence of coronaviruses on inanimate surfaces and their inactivation with biocidal agents. J Hosp Infect. Mar 2020;104(3):246-251. doi:10.1016/j.jhin.2020.01.022

30. Kampf G, Kramer A. Epidemiologic background of hand hygiene and evaluation of the most important agents for scrubs and rubs. Clin Microbiol Rev. Oct 2004;17(4):863-93, table of contents. doi:10.1128/cmr.17.4.863-893.2004

31. Dkhar SA, Quansar $R$, Saleem SM, Khan SMS. Knowledge, attitude, and practices related to COVID-19 pandemic among social media users in J\&K, India. Indian J Public Health. Jun 2020;64(Supplement):S205-S210. doi:10.4103/ijph. IJPH_469_20

32. Gupta L, Gasparyan AY, Misra DP, Agarwal V, Zimba O, Yessirkepov M. Information and Misinformation on COVID-19: a Cross-Sectional Survey Study. J Korean Med Sci. Jul 13 2020;35(27):e256. doi:10.3346/jkms.2020.35.e256

Cite this article : Agrawal A, Agrawal A, Baid T. Attitudes and Practices of Indians during the Covid-19 Pandemic. Int J Med Public Health. 2020;10(4):174-9. 